\title{
Uma Estética da Precariedade: migrações e trocas interculturais no cinema de Ozualdo Candeias (1967-1992) ${ }^{1}$
}

Ângela Aparecida Teles*

\begin{abstract}
Resumo:
Este artigo analisa a relação cinema e história através da estética da precariedade elaborada pelo cineasta Ozualdo Candeias. A mobilidade, a oralidade caipira, a precariedade esteticamente elaboradas através das mesclas entre a ficção e o documentário, da desconstrução de clichês do cinema clássico são trocas culturais, entre o mundo urbano e o rural, suscitadas pelo processo de industrialização e urbanização, vivido intensamente em São Paulo, a partir dos anos 50 do século XX.
\end{abstract}

Palavras-chave: cinema, estética da precariedade, Ozualdo Candeias.

O cinema, como prática sociocultural, é constituído por relações de produção que nos possibilitam acompanhar as experiências de construção de novas sensibilidades, gostos e desejos coletivos iniciadas com a revolução científico-tecnológica do final do século XIX, portanto, relacionada ao processo de crescimento das metrópoles. Para tal empreendimento podemos voltar nossa atenção para o diretor e sua atuação no interior das produtoras, dos estúdios cinematográficos, movimentos e escolas de cinema, atentos aos circuitos de produção, distribuição, exibição e à crítica cinematográfica. Também podemos buscar na narrativa cinematográfica as raízes sociais dos processos de significações.

O filme é uma produção material e pode, então, ser entendido como rastro, como vestígio ao qual o historiador faz perguntas. Não é uma evidência objetiva, neutra, mas saturada pela subjetividade dos sujeitos que a produziram, além de ser obra de arte e constituir-se de uma temporalidade própria. Ao mesmo tempo, produto enraizado em sua época, carregado de historicidade, mas que se projeta além dela. $\mathrm{O}$ cinema é obra de arte constantemente ressignificada; não se refere apenas ao seu tempo vivido, mas também propõe outras realidades, constrói projetos mantendo uma relação tensa de intercâmbio e de confrontação com os processos sociais (Sevcenko,1989). 
A proposta deste artigo é discutir como o cinema, e em específico a obra do cineasta Ozualdo Candeias, produz sentido e provoca experiência temporal a partir da construção narrativa. Por meio do uso de formas, padrões e convenções da linguagem cinematográfica, ou da ruptura e criação de outras convenções, esse diretor apresentou e produziu realidade imagética. Buscamos refletir sobre as mudanças históricas que foram transformadas em cinema a partir de uma experiência singular articulada a processos culturais que envolveram vários sujeitos sociais que elegeram o cinema como um campo estético e político de onde puderam intervir em questões cruciais para a cultura brasileira entre os anos 1950 e 1980.

Candeias nasceu em 1922, no interior de São Paulo, provavelmente em Cajubi, cidade próxima de São José do Rio Preto. Seu pai, um imigrante português, exerceu diferentes atividades e não se fixava, daí sua infância e adolescência terem sido vividas entre a cidade de São Paulo e a região denominada Paulistânia, que compreende o interior de São Paulo, parte de Minas Gerais, Mato Grosso e Goiás, área de influência caipira. A pobreza e os constantes deslocamentos impossibilitaram a Candeias atingir uma escolarização regular. Nas entrevistas que concedeu, quando solicitado a falar de suas origens e dos motivos que o levaram ao cinema, jamais construiu uma narrativa que esclarecesse de maneira causal e linear sua marcha inexorável rumo ao cinema.

Quando falava de si, Candeias o fazia um tanto contrariado e num tom exasperado que também pode ser percebido nos seus filmes. As referências, por exemplo, à vontade de ter sido um "matador profissional" ou ao fato de ter sido "gigolô de puta pobre" são metáforas para as várias funções degradantes que exerceu buscando a sobrevivência e ironizam questões que, a seu ver, não esclareciam nada e podiam transformá-lo apenas em um "diretor exótico". O aprendizado cinematográfico de Candeias, em grande parte autodidata, fez-se em meio a outras atividades profissionais que exercia para manter sua sobrevivência, numa situação financeira sempre instável.

Suas entrevistas sobre sua iniciação no mundo do cinema construíram uma relação meio ao acaso, sem planejamento prévio. Essa forma de construir nexos temporais pode ser encontrada em seus filmes, seja na maneira como seus personagens se colocam no presente e se posicionam em relação ao futuro, seja pela forma como suas produções se efetivavam, em que o roteiro inicial era transformado no meio do caminho, pois as condições de produção e as inúmeras possibilidades surgidas nas locações tornavam a improvisação uma condição necessária para sua finalização. 
O cinema de Candeias não tem como proposta a fruição descomprometida. Buscando realizar um cinema com dimensões políticas, produziu filmes mesclando a narrativa ficcional e a documentária nos formatos curta, média e longa-metragem; em películas $16 \mathrm{~mm}, 35 \mathrm{~mm}$ e em VHS. Nessa construção da ficção cinematográfica acompanham-se os cruzamentos com a fotografia, o jornal, a oralidade caipira e o diálogo com o cinema. Essas práticas sociais da linguagem trabalhadas e ressignificadas nos filmes de Candeias permitem interpretar mudanças socioculturais daquele contexto, décadas de 1950 a 80, constituídas numa estética que tem como leitmotiv a mobilidade e a precariedade experimentadas pelos caipiras pobres no campo e na cidade. Tal processo histórico não diz respeito apenas a questões econômicas ou de mudança geográfica, mas trata do deslocamento cultural, do viver na fronteira, em um processo tenso de hibridação cultural ${ }^{2}$ que permeia a busca por novos territórios e significados para a existência.

Acompanhamos, nessas produções, as diferentes linguagens que se cruzam na construção estética de Candeias, assim como o seu movimento de desconstrução de clichês da narrativa clássica e seu diálogo com o neo-realismo italiano e com o Cinema Novo. Situar a obra deste cineasta em relação a tais movimentos não significa filiá-lo a determinado grupo, movimento ou escola cinematográfica: objetiva-se perceber como respondeu de maneira singular a questões comuns a esses movimentos, que podem ser condensadas na busca por uma narrativa que problematizasse as convenções instituídas no cinema clássico a partir de D. W. Griffit. Essa singularidade de Candeias está relacionada à sua experimentação da cidade e de suas linguagens e como tal vivência concretizou-se em reflexão sobre sua própria trajetória de migrante reterritorializado na cidade com uma sensibilidade apurada para acompanhar, filmar, enquadrar, enfim, problematizar a experiência de outros migrantes na cidade de São Paulo. Interpretamos uma subjetividade, construída entre a cultura urbana e a caipira, que iluminou processos significativos de mudança cultural e de experiência temporal relacionados à industrialização e à urbanização vividas ao longo do século XX em São Paulo e intensificadas entre os anos de 1950 a 1970.

Os filmes A Margem, 1967, Meu Nome É Tonho,1969, Zézero, 1974, Candinho, 1976, A opção ou As Rosas da Estrada, 1981, Manelão, O Caçador de Orelhas, 1982, As Bellas da Billings, 1987, e O Vigilante, 1992, são construções que permitem confrontar discursos e memórias sobre a riqueza e a pujança do maior símbolo da modernização brasileira, introduzindo outros ângulos, outros ritmos e duração que 
questionam a própria noção de modernidade vivida como uma experiência universal, linear e homogênea de aceleração temporal. As misturas, mesclas, diálogos e hibridismos realizados por Candeias problematizaram experiências da "vida na fronteira" de amplos contingentes da população rural que compõem a diversidade cultural da cidade de São Paulo, expondo as mediações que possibilitaram, além do acesso e decifração dos códigos de uma nova cultura, o próprio exercício da tradução cultural.

A estética da precariedade elaborada no cinema de Ozualdo Candeias é uma forma criativa de problematização dos processos de hibridação cultural que se deram ao longo da modernização realizada na cidade de São Paulo na segunda metade do século XX.. Nela surge um tempo híbrido constituído pelos saberes tradicionais, pela experiência histórica da precariedade e do deslocamento das populações rurais, e pela precariedade urbana engendrada pela modernização econômica excludente e pelos meios de comunicação de massa.

\section{Ficção e Documentário: um registro híbrido}

É importante sublinhar que a iniciação de Candeias foi semelhante à de muitos profissionais que desenvolveram seu aprendizado a partir das possibilidades limitadas da produção cinematográfica no Brasil, onde os cinejornais constituíram-se como trabalho mais ou menos contínuo dentro de um mercado dominado pelo filme estrangeiro. Essa atividade foi fundamental para o cinema no Brasil, mesmo sendo considerado um gênero menos digno, pois mesclava os procedimentos da imprensa e do cinema. Os pesquisadores de cinema têm se dedicado pouco aos cinejornais, uma vez que nas suas análises privilegiaram os filmes de ficção, ainda que essa produção tenha sido uma exceção, sobretudo no período do cinema mudo (Bernadet, 1995).

A importância do cinejornal, ou das chamadas "atualidades", para o desenvolvimento do cinema, vem sendo documentada pela historiografia mais recente, que mudou o enfoque sobre as imagens produzidas entre 1895-1905, antes da constituição da narrativa clássica, em 1915, por D. W. Griffit. Para esses pesquisadores, não se trata de pensar as primeiras imagens moventes como um pré-cinema ou um cinema primitivo, mas como uma multiplicidade narrativa latente do cinema que apontava para experiências temporais em curso e inúmeras relações com as diferentes formas de diversão e linguagens existentes nas cidades. As novas formas de informação 
e entretenimento que atraíam multidões participaram da formatação das narrativas fílmicas num momento em que não havia um padrão instituído e consagrado de linguagem cinematográfica e a experimentação provocava e exigia outro comportamento do espectador diante das imagens moventes. Estes trabalhos mostram como as exposições universais, os cartazes, a fotografia, o fotojornalismo, os museus de cera e os catálogos formaram um público receptivo ao cinema. $\mathrm{Na}$ atualidade, é senso comum o suposto poder das imagens cinematográficas ou televisivas em influenciar nossa compreensão do mundo, mas esses trabalhos mostram como o discurso imagético se constituiu a partir de diferentes suportes de comunicação e de entretenimento até tornar-se um divertimento de massa (Charney; Schwartz, 2001).

As imagens do primeiro cinema, período entre 1895-1915, aparentemente absurdas e de difícil entendimento, estavam ancoradas nas histórias que circulavam nos jornais da cidade e o público que assistia às projeções animadas em meio a outros divertimentos baratos, como os vaudevilles, também lia esses jornais. Portanto, no primeiro cinema, de acordo com (Costa, 1995), assim como nos jornais, era possível acompanhar os acontecimentos das ruas da cidade, ou melhor, de uma cidade tornada espetáculo nesses espaços de comunicação e de divertimento. Essas imagens descontextualizadas apresentam-se desconexas e podem ser reduzidas a uma linguagem primitiva ou a um pré-cinema se se busca uma evolução inexorável em direção à narrativa clássica do cinema. Tomadas no seu contexto, elas apresentam as mudanças de percepção em curso naquele presente e a construção de novas sensibilidades surgidas com o crescimento das metrópoles na Europa e nos Estados Unidos na virada do século XIX para o seguinte.

Nessas primeiras imagens moventes, ainda "selvagens", não há a separação nítida entre ficção e documentário e as atualidades foram uma forma de produção de imagens na qual a noção de realidade pode ser problematizada - mesmo num período em que o grande atrativo da fotografia e das imagens em movimento era a possibilidade de "captar a realidade" tal como ela se apresentava. As atualidades no primeiro cinema se constituíam de eventos, festas comemorativas captadas no seu acontecer ou "fatos acontecidos" e de conhecimento do público-alvo, como lutas de boxe ou crimes famosos. Portanto, as imagens captadas em locação, no calor dos acontecimentos - ou esses acontecimentos encenados -, eram atualidades, pois "realmente haviam acontecido". 
No Brasil também havia o interesse pelas atualidades ou filmes naturais nos primórdios do cinema, até o filme de ficção se impor como o divertimento preferido dos espectadores. Para a produção nacional e, em específico, a paulista, as atualidades, na forma de cinejornais, tornaram-se a única possibilidade de sobrevivência para os cinegrafistas, sobretudo após o advento do cinema falado.

O cenário para o filme de ficção era pouco promissor nos anos 1950, quando Candeias começou a se envolver com o cinema, apesar das experiências da Cinédia e da Atlântida, no Rio de Janeiro, e da Vera Cruz, da Maristela e da Multifilmes, em São Paulo, para mencionar apenas o eixo Rio-São Paulo. Trabalhar para cinejornais regulares ou produzir reportagens para órgãos oficiais ainda era uma forma de sobreviver nesse meio, pois, apesar de o jornal ter sido o principal meio de comunicação até os anos 1930, naquele contexto (anos 50 e 60), o rádio e o cinema falavam mais a uma população com baixas taxas de escolarização e de baixo poder aquisitivo (Souza, 2003).

A relativa autonomia na execução do trabalho como cinegrafista de atualidades foi fundamental para Candeias. Produzir, roteirizar, filmar e montar davam-lhe a possibilidade de experimentar, de improvisar e de criar com poucos recursos. Essas reportagens eram encomendadas e era necessário disfarçar o tom oficial - daí que, nesses primeiros trabalhos, a reportagem era em grande medida encenada, ficcionalizada. Também havia uma preocupação em filmar aquilo que, na concepção desse diretor, poderia atrair atenção do espectador, pois esse dado ou era importante na hora de vender a reportagem ou era uma exigência daqueles que financiavam o cinejornal. Mas como saber o que chamaria ou não a atenção do espectador? Prestando atenção aos temas que circulavam no rádio e, sobretudo, nos jornais de apelo popular, ou seja, aqueles que veiculavam curiosidades, crimes, fatos inusitados que ocorriam na cidade. Uma assertiva do diretor sobre sua inspiração para a composição de uma das histórias dos casais que perambulam no filme $A$ Margem é significativa:

\footnotetext{
A Margem foi o seguinte: eu inventei a porra da história a partir de umas coisas que eu tinha lido num jornal - que eu leio jornais -, daí eu cato essas coisas e enfio na história. Eu vi a notícia de uma mulher que estava esperando o noivo pra casar, ele não apareceu, ela nunca mais tirou o vestido e saiu por aí afora. O resto eu inventei, mesmo. O que me motivou foi essa mulher do véu, que ela não tirou mais. (Puppo, 2002, p. 20)
}

O jornal foi importante para Candeias, construindo sua relação com a escrita da cidade. Além de seu andar pelas ruas, o caminhar por entre as notícias e imagens veiculadas ofereceu o material para a percepção e narração da cidade. É claro que a 
história "verídica" da mulher abandonada pelo noivo não é o aspecto mais realista do filme, ao contrário, constrói uma atmosfera quase surrealista. O "realismo", o tom documental dessa ficção, vem das locações, dos figurinos, dos personagens e da exposição de uma miséria que confrontava a imagem de pujança da maior metrópole brasileira. O termo exposição é adequado, pois a câmera de Candeias, ao acompanhar lentamente o vagar dos personagens pelas margens do rio Tietê, vivendo em condições precárias e buscando a sobrevivência diária, documenta e esquadrinha a margem onde a vida parecia inviável. É nesse ponto que esse filme tem importância social, cultural e política para seu diretor, porque ele, antes de tudo, registra através da ficção, chama a atenção para o cotidiano de personagens que vivem à margem na cidade.

A deambulação presente nesse filme e em outros pode ser relacionada à avantgarde francesa dos anos 1920 e 30 ou à nouvelle vague dos anos 1960 ou a outras temáticas universais, como apontado por alguns críticos, mas possui uma singularidade para além das paisagens e tipos físicos característicos. Os caminhantes de Candeias são sempre impelidos pelo imperativo da sobrevivência. Seus personagens não vagam a esmo por um vazio existencial ou compelidos pelas transformações capitalistas daquele contexto específico, o deslocamento constante fazia parte da experiência histórica das populações pobres no Brasil.

No caso dos caipiras, os traços que vêm da miscigenação do português com o indígena e da experiência histórica das bandeiras são elementos que constituíram a transitoriedade e a mobilidade como parte do seu modo de vida, voltado para o que Candido (2004) denominou cultura da subsistência. Mas um dado histórico do desenvolvimento capitalista brasileiro também deve ser observado nessa premência pelo deslocamento entre os pobres.

\footnotetext{
Mobilidade provocada, sem dúvida, por um sistema que relegava aos homens livres um viver à margem e um aproveitamento residual, a estrutura da sociedade escravocrata engendrou homens andarilhos, "sem vínculos, despojados, a nenhum lugar pertenceram e a toda parte se acomodaram". Mobilidade intensificada pelo monopólio da propriedade da terra, pelos grandes latifúndios e pela presença de escravos, num território que oferecia grandes extensões ainda não ocupadas, mudar de lugar sempre foi hábito dos homens livres pobres. (Wissenbach, 2004, p. 57)
}

Deslocar-se constantemente não deve ser interpretado como uma incapacidade para o trabalho sistemático. O estereótipo do caipira preguiçoso já foi suficientemente desconstruído e as razões dessa mobilidade estão relacionadas à necessidade de sobrevivência, de escapar da fome, da posse precária da terra e das vicissitudes que impediam a sobrevivência ${ }^{3}$ 
O processo de aceleração industrial e de urbanização vivido no Brasil a partir dos anos 1950 e intensificado nas duas décadas seguintes, particularmente em São Paulo, representou uma inflexão na situação dos pobres no Brasil? A cidade possibilitou a fixação e condições de vida que permitiram às populações vindas do campo escapar à precariedade? A miséria e a contingência, supostamente ligadas a elementos arcaicos do mundo rural brasileiro, foram superadas pela modernização? A São Paulo acelerada, pujante e moderna exaltada durante os festejos do IV Centenário (1954) pela propaganda oficial ou promovida por empresários nos meios de comunicação destinada a atrair mão-de-obra de outros Estados brasileiros está ausente nos filmes de Candeias. Os enredos, os personagens e as formas criadas por ele registraram, ficcionalizaram uma nova precariedade vivenciada na cidade mais industrializada e urbanizada do Brasil.

Como enfatizou Costa (1995), o cinema nasceu vinculado à idéia de mostrar a realidade da cidade e de lugares longínquos na forma de atualidades filmadas ou encenadas. Esse traço documental está presente no cinema de Ozualdo Candeias, na forma de cinejornal, documentário ou ficção. Seu cinema sempre buscou informar, documentar as questões atuais, fossem as mais pontuais ou as de longa duração, como é o caso da mobilidade e da precariedade das populações desterritorializadas e o processo contínuo de adaptação e reconstituição de seu universo cultural desestabilizado pelo capitalismo brasileiro. Mas essa preocupação com a realidade a ser apresentada no cinema também fez parte das discussões e polêmicas suscitadas pelo cinema moderno que, de diferentes formas e por meio de vários cineastas, questionou a narrativa clássica.

Os cineastas que se propuseram a "modernizar" o cinema questionavam o traço narrativo herdado do melodrama. De acordo com Xavier (2003, p. 39-43), o melodrama constituiu-se como o gênero no qual a expressividade máxima é buscada na voz, no gesto e nos trejeitos do olhar, exageradamente construídos para tornar visíveis os aspectos psicológicos e morais, mostrando a crença no acesso a uma verdade oculta após uma luta incessante contra toda sorte de vilania e trapaças. O olhar é solicitado a reconhecer as formas mais imediatas do bem e do mal. A técnica do cinema afinou-se com essa forma de representação criando o "olhar melodramático", que acabou por "modernizar o melodrama" ao permitir que a expressão teatral abandonasse os excessos do século XIX. Esse crítico enfatiza que já nas primeiras décadas do século XX artistas ligados à arte moderna fizeram outra leitura do cinema, buscando seu potencial revolucionário sufocado pelo ilusionismo baseado no melodrama e apostando na sua superação e na libertação do "olhar sem corpo" da continuidade narrativa. Entre esses 
movimentos destaca o cinéma d'avant-garde dos anos 1920, liderado por Jean Epstein e Germaine Dulac, e o surrealismo. O cinema desejado seria aquele criador do espaço utópico da verdade - em oposição ao espaço da mentira identificado com o ilusionismo travestido de realismo no cinema industrial. O cinema seria capaz de captar e revelar a verdade secreta, à qual nosso olhar limitado seria incapaz, ou revelar as pulsões e o inconsciente.

Já o neo-realismo, surgido na década de 1940, foi uma experiência cinematográfica que buscou trazer à tona o potencial revolucionário do cinema por outros caminhos, através de alguns procedimentos como a filmagem em externas e em cenário natural, por oposição aos estúdios cinematográficos; pelo recurso a atores nãoprofissionais e por personagens longe da caracterização dos heróis de feitos extraordinários; em que a ação se rarefaz em oposição a acontecimentos extraordinários, reviravoltas e toda sorte de qüiproquós comuns à tradição melodramática do cinema clássico (Vernet, 1995,p. 136-140).

No Brasil, o Cinema Novo postulou a criação de uma estética que expressasse a condição da pobreza, da miséria e do subdesenvolvimento do Brasil, e nesse sentido fez parte do movimento de constituição de cinematografias nacionais que se fez no embate contra a hegemonia do filme americano a partir dos anos 1950 (Xavier, 2001). Vários cineastas em diferentes países se colocaram como condição para o florescimento de uma arte cinematográfica autóctone o combate ao filme americano e ao poder financeiro que este representava. Realizaram esse embate através da luta por espaços de exibição e pela inovação da narrativa. No manifesto Uma Estética da Fome, Glauber Rocha sublinhou características do Cinema Novo e de sua ambição política e estética (Rocha, 1965).

Cada cineasta agrupado no Cinema Novo construiu sua cinematografia tendo como baliza tais preocupações, ainda que as diferenças individuais devam ser consideradas para que o grupo não seja homogeneizado. É possível perceber três vertentes que estão na base desse movimento: as experiências neo-realistas do cineasta Nelson Pereira dos Santos, a partir de Rio 40 Graus, de 1954, e do cineasta Roberto Santos, com O Grande Momento, de 1955; a influência da crítica francesa, com a política dos autores preconizada pelos Cahiers $d u$ Cinema, tendo como base as reflexões do crítico André Bazin e no Brasil o movimento de valorização do cinema através da formação de profissionais na Europa; do movimento dos cineclubes, das lutas políticas travadas nos seminários de cinema e, ainda, o surgimento de novas tecnologias - câmeras leves, gravadores Nagra que permitiam a captação do som direto e película 
sensível - que permitiram uma maior agilidade, daí o slogan "uma idéia na cabeça e uma câmera na mão". Além desses fatores, ressalte-se a importância do Centro Popular de Cultura (CPC) e a sintonia do cinema com outras práticas artísticas, como a música, o teatro e as artes plásticas (Ramos; Miranda, 2000, p. 144).

Candeias não se vinculou explicitamente a nenhum movimento cinematográfico nacional, Cinema Novo ou cinema marginal, mas sua obra, sem dúvida, foi influenciada pelas experiências neo-realistas aqui realizadas e pela adesão ao projeto político de busca por uma cinematografia voltada para os problemas nacionais. Sua caracterização da realidade do homem do campo desterritorializado confronta as construções abstratas do povo brasileiro como força revolucionária presentes, por exemplo, em Deus e $O$ Diabo na Terra do Sol, obra seminal de Glauber Rocha. Os questionamentos presentes na opção pela produção em locações, feita com poucos recursos financeiros, e na opção pela narrativa fragmentada são traços comuns entre a sua obra e obras do Cinema Novo.

Os críticos de cinema, Rubens Biáfora e Moniz Vianna, desafetos de Glauber Rocha e do Cinema Novo, incensaram A Margem, 1967, como uma representação mais verdadeira do povo brasileiro. Este filme foi premiado, o que não ocorreu, por exemplo, com Terra em Transe, lançada no mesmo ano. O interessante a sublinhar é que esses cineastas concebiam a prática cinematográfica como um espaço de luta política onde seria possível dar forma às mazelas sociais e políticas que afetavam os diversos grupos sociais naquele contexto. Cada cineasta realizou essa proposta estética e política a partir das suas experiências culturais.

\section{Desconstruindo Clichês Cinematográficos}

Para apresentar a realidade de maneira que engaje o espectador, Candeias rompeu cânones do cinema clássico hollywoodiano, uma vez que as convenções narrativas desse cinema não provocariam a fruição estética desejada. A construção da montagem, da sonorização, do cenário e dos personagens buscando representar o "tipo brasileiro" e a "paisagem brasileira" constituiu um tempo presente permeado pela sobrevivência em meio à pobreza e à violência. Saturando a tela com a miséria brasileira, Candeias construiu uma realidade feia, violenta e precária, composta e experimentada em sua intensidade a partir de procedimentos estéticos que assumiram essas características na própria forma cinematográfica ${ }^{4}$. 
Para a interpretação dessa estética da precariedade, começo pelos personagens recorrentes nos filmes de Candeias e uma nova fotogenia produzida pela composição de tipos étnicos resultantes da mestiçagem entre a população pobre. Através da construção de personagens-emblema das mesclas culturais é possível acompanhar as nuanças da reflexão do diretor sobre a cultura brasileira. A elaboração desses personagens a partir de traços étnicos, assim como sua caracterização psicológica, foi confrontada com a subjetividade burguesa representada na narrativa clássica. A mobilidade desses personagens por espaços abertos, em ruínas ou degradados pelo lixo urbano foi o outro elemento da narrativa analisado.

Aqui se faz necessário definir cinema clássico. A reflexão de Jorge Furtado sobre o que seria um clássico no cinema, ou o cinema clássico, aborda elementos essenciais para a comparação com o processo criativo de Candeias. Cinema clássico foi tomado aqui no sentido de padrão dominante da narrativa cinematográfica elaborado pelo cinema americano nos últimos 50 anos e construído sobre uma estrutura narrativa dramática em três atos.

Em resumo: descrição do mundo comum, o herói-protagonista é chamado à aventura, inicialmente recusa, encontra seu mentor e acaba aceitando o convite, então viaja ao mundo especial (oposto ao mundo normal onde a história começa), recebe a chave, ultrapassa um portal, enfrenta provas, conhece inimigos e aliados, desobedece o mentor, enfrenta o antagonista, triunfa e regressa, transformado, ao mundo normal para dividir com seus pares (e com os espectadores) os frutos (o elixir) e descobertas de sua aventura. (Coutinho, Xavier, Furtado, 2005, p.100)

Complementando essa estrutura narrativa - presente não apenas no cinema -, há os procedimentos narrativos que se tornaram convenções eficientes e partilhadas por espectadores de vários países. A primeira delas é o desconhecimento da presença da câmera pelos personagens - personagens jamais olham para a câmera -, cenas que só mostram aquilo que interessa ao desenvolvimento da trama, ou seja, o espaço diegético construído jamais é rompido; figurinos e situações que simulam uma realidade plausível em que as ações sempre possuem uma justificativa e não há dúvidas ou ambigüidades na trama desenvolvida. "A linguagem deve permanecer escondida, de modo que o espectador em nenhum momento lembre-se de estar no cinema. O padrão é a ficção, cuja 'suspensão da descrença' permite usufruir com segurança o prazer do jogo dramático" (ibidem, p. 101). Além dessas convenções narrativas sublinhadas por Furtado, destaco outras, referentes à fotogenia e aos ambientes assépticos construídos em estúdios. 
No universo imagético erguido por Candeias os elementos da narrativa clássica foram questionados através de um motivo recorrente: personagens de origem rural são postos em movimento sem que dele resulte a chegada a algum lugar, levando à clássica solução dos problemas enfrentados pelo protagonista. O narrador constantemente abandona o protagonista e passa a acompanhar o caminhar a esmo e sem destino de outros personagens, que não contribuem para a resolução da trama. No filme $A$ Margem não há referência explícita à origem dos protagonistas ou qualquer indício da condição de migrantes rurais, o que não impede o narrador de registrar em um breve travelling uma família de migrantes caipiras à beira de uma estrada, a sugerir sua recente chegada a São Paulo e a situação de incerteza e abandono em que se encontram. Intuímos essa jornada daquela família, mas o narrador não constrói uma explicação causal que se prolongue no presente.

No longa-metragem seguinte, Meu Nome É Tonho, de 1969, o diretor brincou com os clichês do western americano, ao mesmo tempo em que buscou caracterizar o mundo rural brasileiro em Vargem Grande Paulista, local das filmagens de $O$ Cangaceiro, do diretor Lima Barreto, em 1954. Nele o protagonista é indeciso e ambíguo e só passa a agir motivado pelo incesto que praticara sem o saber. O filme Zézero, de 1974, é uma parábola sobre o caipira que migra atrás das promessas de melhores condições de vida que chegavam ao campo pelos meios de comunicação representados por uma sereia tosca. Nessa parábola o protagonista é definido pelo narrador como um Zé Ninguém facilmente manipulável e irresponsável em relação à sua família. O seu retorno vitorioso após vencer na Loteria Esportiva não permite que ele divida as honras de sua glória com os seus, pois os encontra mortos e apenas recebe como coroação final o gesto obsceno da sereia tosca que o havia seduzido.

Em $O$ Candinho, 1976, o filho de uma família de trabalhadores rurais parte para a cidade em busca de um santo milagroso, após sua família ter sido expulsa da fazenda onde trabalhavam. Esse personagem é literalmente um doido, um alienado mental que, após passar uma série de privações em busca de um santo milagreiro, foi encontrá-lo tomando café com o seu algoz. Diante da possibilidade da luta armada que se coloca ao final de sua jornada, permanece indeciso. O filme Aopção, 1981, aborda o deslocamento de mulheres da zona rural para a cidade, entre elas, uma bóia-fria do interior de São Paulo. A jornada dessas heroínas é permeada por uma série de atos de violência que inclui necessariamente a violação de seus corpos e a prostituição. A chegada à terra 
prometida não garante a felicidade a todas, pelo contrário, muitas delas encontram a morte trágica ao fim da jornada.

No filme Manelão, o Caçador de Orelhas, de 1982, filmado no Centro-Sul do País, acompanha-se a trajetória de um caboclo doente que se transformou em matador profissional. O protagonista deste filme é o avesso do caubói viril dos westerns e também muito distante do heroísmo dos cangaceiros e das versões brasileiras do justiceiro destemido. Em As Bellas da Billings, de 1987, a trajetória de um violeiro que procura desenvolver sua carreira artística em São Paulo se entrelaça à de outros personagens que circulam na Boca do Lixo. O protagonista James, um semi-alfabetizado que faz pose de intelectual, vive de expedientes e do lixo que as irmãs recolhem nos restaurantes da cidade. Por fim, em $O$ Vigilante ,1992, novamente se trata de um grupo de bóias-frias que migra para São Paulo buscando melhores condições de trabalho e acaba por se envolver na violência das favelas da periferia de São Paulo. A trajetória do protagonista é ainda menos heróica, pois se trata de um bóia-fria que desejava ser músico e na cidade torna-se vigilante e, por último, matador.

Para realizar esteticamente o projeto de mostrar a realidade brasileira, Candeias se insurgiu agressivamente contra a estrutura da narrativa clássica, através da desmistificação da história teleológica de um herói protagonista. Seus protagonistas não possuem as qualidades que funcionam dentro das convenções, ou seja, o choque e a agressão ao espectador por meio da negação em dar-lhe o que ele sempre espera encontrar fazem parte da sua estratégia narrativa. Observa-se então um movimento no cinema de Candeias que consiste em caracterizar seus personagens como alteridades em relação a clichês cinematográficos do cinema americano e do brasileiro e a composição desses mesmos personagens como "tipos físicos brasileiros", num embate físico constante na fronteira entre o mundo rural e o urbano, buscando sobreviver a esse meio hostil.

Por meio do personagem mestiço com traços indígenas, cuja identidade está fragmentada em diferentes papéis sociais e experiências culturais presentes no filme $O$ Candinho, o narrador constrói o mundo urbano como um lugar de desestruturação da família e das culturas indígenas. O pai mestiço, composto de múltiplas referências religiosas - a tradição cristã, as práticas indígenas e a religiosidade de matriz africana misturadas na cultura rural -, mobiliza esses fragmentos para sobreviver em meio à precariedade da cidade. O índio Jupiá, personagem de As Bellas da Billings, também sobrevive nas ruas próximas à Praça da Sé vendendo o conhecimento tradicional de seu 
povo sobre plantas medicinais. Através desses personagens e das referências à violência que envolve a disputa por terras indígenas no Brasil, o narrador desmonta qualquer visão romântica do índio brasileiro como reserva pura de nacionalidade e elabora da sua perspectiva uma versão para "a marcha para o Oeste", constituída em épico fundador dos Estados Unidos pelos faroestes de Hollywood.

Os matadores profissionais, protagonistas dos filmes Manelão, o Caçador de Orelhas e de $O$ Vigilante, são verdadeiros monumentos iconoclastas contra o western, o gênero cinematográfico norte-americano por excelência, e também um gesto demolidor da mistificação em torno da valentia, da coragem e da honra de pistoleiros que circulavam também em produções brasileiras caracterizadas como westerns. Em Manelão, o Caçador de Orelhas, a sentença-emblema do protagonista é dita nestes termos - "Eu nunca matei ninguém. Ora essa. É a minha vara de mijo ou a orelha de num sei quem. Acho que vou matar". Candeias substituiu os motivos desencadeadores da ação no western, evidentes nas falas dos heróis (como a vingança, a honra, a defesa da mulher, da família e da propriedade) pela preservação da virilidade no nível mais baixo, que é manutenção do próprio órgão genital. Ele também fez ruir qualquer idealização da vida no campo, mostrando os elementos de violência e de pobreza que compunham o universo de homens que vagam pelo sertão brasileiro em busca da sobrevivência. Nenhuma causa superior os motiva, a contingência e o acaso reduzem esses homens pobres à condição de sobreviventes que se agarram a qualquer expediente para vencer o meio que insiste em hostilizá-los.

Em $O$ Vigilante, o narrador, ainda que seja ambíguo e pareça apoiar a saída elaborada pelo caipira para fugir à violência na favela, constrói o matador com ironia, a partir de fragmentos de histórias de matadores que circulavam em quadrinhos. Mas a realidade é mais cruel do que os cenários das histórias em que se movem os lendários matadores, pois, ao ser obrigado a ganhar a estrada novamente, o vigilante encontra um grupo de crianças transformadas em pesadelo pela realidade social das favelas e que acabam por confrontá-lo numa cena final em que disparos insinuam um massacre em meio a risos infantis aterrorizantes.

Volte-se agora a atenção para a personagem da prostituta, presente em todos os filmes aqui mencionados. No mundo ficcional construído por Candeias as vicissitudes vividas por aqueles que são obrigados ao deslocamento como estratégia de sobrevivência são intensificadas na personagem da mulher pobre transformada em prostituta. O narrador sempre acompanha suas personagens femininas, buscando 
mostrar a violência a que estão submetidas no contato com um mundo essencialmente masculino. Em A Margem, a prostituta negra vive de enganar e roubar os caminhoneiros que circulam pela Marginal do Tietê, até se apaixonar e morrer sem consumar o seu casamento. Em $O$ Candinho a prostituta é responsável por garantir sua sobrevivência e a de sua família. Em Zézero as prostitutas que se oferecem nos alojamentos para trabalhadores da construção civil experimentam a violência do operário caipira que não pode pagar pelo sexo, em cenas ásperas que constroem o encontro entre o homem e a mulher como embate entre animais ferozes. Em As Bellas da Billings, Glória, já idosa, sente saudades e chora ao ouvir uma canção que a faz se lembrar de um amor do passado. Além de Glória, suas amigas e travestis que vivem na Boca do Lixo são acompanhados em suas jornadas diárias pelo narrador. No filme Aopção todas as mulheres que tomam a estrada sem rumo definido acabam se prostituindo. Por último, em Meu Nome É Tonho, todas as filhas e esposas dos pequenos proprietários que foram mortos e tiveram suas terras griladas por um bando local são levadas a um prostíbulo. Se para o caipira pobre havia poucas possibilidades de se integrar a um mundo que o excluía, para a mulher a prostituição era uma condição contra a qual era impossível lutar.

Esse determinismo presente nos filmes, sobretudo em torno da prostituta, é um dos traços mais incômodos da obra de Candeias. Observa-se que o narrador, nesses diferentes filmes, está preocupado em mostrar a dimensão humana dessas mulheres e os múltiplos papéis que desempenham como mãe, como mulher e como filha. Ele também sugere que a luta contra a precariedade é sempre mais dolorosa para as mulheres e que os estereótipos construídos sobre elas no cinema estão muito distantes da realidade das mulheres pobres, que precisam sobreviver num mundo masculino que sempre as exclui. Toda grossura, feiúra e sordidez da realidade precária na qual estão imersos os personagens de Candeias são potencializadas ao máximo na prostituta. Também o personagem portador de deficiência física e mental pode ser pensado como um emblema das limitações e das privações às quais os marginalizados estão submetidos. Esses personagens, a prostituta e o deficiente, confrontam os ideais de beleza, de higiene e de harmonia evocados no cinema americano.

A câmera de Candeias faz um inventário minucioso do tipo humano integrado em seu ambiente. Mestiços, índios, negros, caipiras, prostitutas e deficientes perambulam por paisagens urbanas e rurais, constituindo um mapa fisionômico e topográfico do Brasil. Campo e cidade, natureza e civilização não são polaridades 
construídas no cinema de Candeias, por isso ele opera uma desconstrução de clichês em torno de um Brasil mestiço, idílico, dádiva de uma natureza dócil e romantizada, ou de um Brasil pujante economicamente.

Essa apresentação de tipos brasileiros em interação com o meio e em constante mobilidade do campo para a cidade é um dos elementos que compõem o que estou nomeando como estética da precariedade. Na direção de atores, Candeias não prioriza a atuação, pois não há preocupação em construir uma subjetividade burguesa tal como se apresenta no melodrama. Seus personagens, ou "tipos brasileiros", estão sempre buscando sobreviver em um meio hostil e esse combate é permanente. O diretor apresenta esse embate vivenciado cotidianamente sem recorrer às motivações pessoais, apenas narra a luta pela sobrevivência travada no presente entre o homem e o meio.

Assim, o caipira protagonista de Zézero é um caboclo, e sua família é composta por mulatos e caboclos, seus companheiros de obra e as prostitutas também são mestiços dos mais variados matizes. Em $O$ Candinho registra-se a presença de índios, mamelucos e mestiços. Em A Margem há uma profusão de negros e mulatos, a começar pela protagonista. Nota-se, assim, a preocupação do diretor em "mostrar" o "verdadeiro" rosto brasileiro na tela, muito longe do padrão de beleza anglo-saxão regularmente apresentado nas fitas americanas.

A agressividade iconoclasta contra as formas consagradas da cinematografia, através das quais um determinado imaginário sobre o Brasil circulou ${ }^{5}$, também denunciou como estereótipos as imagens construídas sobre o homem brasileiro. Um Brasil feio e miserável sobrevive e pulsa nos filmes de Candeias. A vida da população pobre do campo que migra para a cidade não muda substancialmente, mas é tomada pela precariedade e miséria presentes na cidade. Essa permanência no presente deve ser escancarada pelo cinema e provocar reações. Não se trata de pura agressão, mas de uma provocação, que pretende "dar um recadinho", chamar a atenção para os problemas, mas que se recusa a apontar um caminho. O que o cineasta propõe é encarar nossas mazelas sem a mediação de melodias suaves, ambientes modernos e higiênicos, rostos bonitos ou natureza primorosa.

Que se pense no carro de boi, uma das imagens de um Brasil rural constante em Humberto Mauro e também trabalhada por Nelson Pereira dos Santos em Vidas Secas e por Walter Lima Jr. em Inocência. Se em Mauro pode ser entendido como um aliado persistente, mesmo diante das mudanças que avançavam sobre o campo nos anos 50, no filme Meu Nome É Tonho, 1969, o carro de boi é utilizado para transportar os corpos 
dos posseiros assassinados e que tiveram suas terras griladas por um bando local. Em Manelão, o Caçador de Orelhas, 1982, o carro de boi apresenta a lentidão, o atraso e a pobreza do sertão mineiro. Com esses procedimentos Candeias propõe outra leitura do Brasil rural, ironizando e se insurgindo contra imagens que da sua perspectiva não apresentavam a realidade brasileira.

Através dos procedimentos de agressão e de ruptura com os elementos da narrativa clássica, como o desenvolvimento da jornada do protagonista, o rompimento da diegese e a crítica ao cinema brasileiro, Candeias compôs um cinema a partir da destruição e inversão das bases de sustentação do cinema americano, constituído como o grande inimigo do cinema brasileiro. Fazer cinema brasileiro não significava, para esse diretor, tratar de "temas ou de paisagens brasileiras", mas tratá-los numa outra forma cinematográfica que não fosse a consagrada pelo império hollywoodiano. Por isso, sua mise-en-scène deveria exacerbar, chocar através da violência dos temas e das formas narrativas: só assim toda a violência, miséria e precariedade que constituíram historicamente a mobilidade de amplos contingentes da população pobre brasileira seriam capazes de produzir indignação e uma reação no público.

Para completar essa proposta de fruição das imagens em movimento o diretor provocou outros deslocamentos por meio da experimentação realizada na banda sonora e elegendo a oralidade e a música caipiras como elementos característicos das imagens mais verdadeiras do Brasil. A fala caipira e as modas de viola compõem quase que integralmente a banda sonora dos filmes As Bellas da Billings, O Vigilante, Meu Nome É Tonho,Aopção, Manelão, o Caçador de Orelhas e A Herança. No fillme O Candinho, um cururu produz um choque entre as imagens e a banda sonora, problematizando a pregação religiosa como forma de alienação da população rural. Em Zézero a moda de viola reforça as imagens e costura a narrativa. A oralidade caipira também está presente nas poucas falas dos personagens dos filmes citados, assim como as festas populares, como a congada, a Folia de Reis e as cantorias dos violeiros. Mas essas manifestações não são apresentadas como algo típico ou externo às películas: elas se combinam para construir de maneira coerente o universo do caipira, que nesses filmes não foi caracterizado como arcaico ou anacrônico, ou seja, marcado através de uma dicotomia entre o campo e a cidade. Tais permanências são vivenciadas e ressignificadas apontando para a adaptação do homem do campo na cidade. Se a vida do caipira foi desestruturada com o processo de desenvolvimento capitalista que atingiu o campo e a 
cidade, essas práticas culturais ainda estavam vivas naquele presente e interagiam com outros elementos da cultura urbana; seus filmes são produções desse processo.

$\mathrm{Na}$ estética da precariedade há uma narrativa da experiência histórica brasileira a partir do tempo presente, fraturado pela presença de sujeitos históricos marginalizados. Os personagens de Candeias experimentam o tempo presente como a única possibilidade de continuarem vivendo, e as práticas e os valores que permanecem da experiência do mundo rural, apesar dos sucessivos deslocamentos, não são vividos como distância temporal ou como saudosismo de algo que não existe mais. Essas permanências são atualizadas pelo presente e são mobilizadas no processo de reterritorialização na cidade, sempre realizado às margens da cultura dominante. Tais presenças expropriadas e marginalizadas não são portadoras de nenhuma promessa revolucionária a ser realizada no futuro, nem sua tradição é uma reserva pura de nacionalidade com a qual se possa reinventar o País, pois são presenças ignoradas historicamente. Mas, acima de tudo, esses sujeitos marginalizados ao longo do desenvolvimento capitalista brasileiro não precisam de uma vanguarda iluminada que fale em seu nome, nem de piedade e comiseração do Estado brasileiro ou dos espectadores, que descobrem essas presenças ao aceitarem acompanhar a câmera de Candeias pelos espaços inusitados que ele construiu.

A estética da precariedade engendrou um tempo híbrido ao articular imageticamente a mobilidade e a precariedade dos migrantes pobres. A experiência de vida na fronteira desses personagens foi construída pelas mesclas entre a cultura oral caipira - suas falas, sua música, assim como as narrativas orais na forma de "causo" ou de parábolas - e as linguagens urbanas do cinema, da fotografia e do jornal. Na construção temporal constitutiva dessa estética há uma concepção do tempo que entende a "experiência da modernidade como repleta de justaposições anárquicas, encontros aleatórios, sensações múltiplas e significados incontroláveis" (Charney, 2001, p.392), portanto, a natureza da percepção na modernidade é composta por fragmentos que embaralham a percepção do tempo como uma continuidade. O movimento esvazia a certeza da presença estável e o instante é algo fugidio que salta para fora da continuidade temporal, questionando as crenças na ideologia do progresso. Essa percepção do tempo aparece problematizada pela fotografia, pelo cinema moderno e pela literatura.

Essa percepção moderna do tempo aparece mesclada a outro elemento que compõe o tempo híbrido da estética da precariedade. Este outro elemento é a noção do 
tempo daqueles que construíram sua subjetividade na vivência em meio à pobreza e a contingência que impõe como premência o colocar-se em movimento sempre, sem nunca se voltar para trás, pois há o risco de não sobreviver ${ }^{6}$. A morte é o fim certo, por isso, projetar o futuro torna-se inútil e desnecessário, o importante é pulsar e sobreviver no presente.

\section{REFERÊNCIAS BIBLIOGRÁFICAS:}

BAKHTIN, Mikhail. Marxismo e Filosofia da Linguagem. São Paulo: Hucitec, 1981.

BERNADET, Jean-Claude. Historiografia Clássica do Cinema Brasileiro: metodologia e pedagogia. São Paulo: Anablume, 1995.

CANCLINI, Nestor Garcia. Culturas Hibridas: estratégias para entrar e sair da modernidade. 4. ed. São Paulo: Edusp, 2003.

CANDIDO, Antonio. Os Parceiros do Rio Bonito. 10. ed. São Paulo: Duas Cidades/Editora 34, 2004.

CHARNEY, Leo; SCHWARTZ, Vanessa R. (Orgs.). O Cinema e a Invenção da Vida Moderna. São Paulo: Cosac \& Naïf, 2001.

CONTRACAMPO. Revista de Cinema. Dossiê Ozualdo Candeias, n. 25/26, 2001.

Disponível em <http://www.contracampo.com.br>. Acessado em 15 nov. 2004.

COSTA, Flávia Cesarino. O Primeiro Cinema: espetáculo, narração, domesticação. São Paulo: Scritta, 1995.

COUTINHO, Eduardo; XAVIER, Ismail; FURTADO, Jorge. O Sujeito (Extra) Ordinário. In: MOURÃO, Maria Dora; LABAKI, Amir (Orgs.). O Cinema do Real. São Paulo: Cosac \& Naïf Edições, 2005.

MARTINS, José de Souza. A Vida Privada nas Áreas de Expansão da Sociedade Brasileira. In: SCHWARCZ, Lilia Moritz (Org.). História da Vida Privada no Brasil v. 4. Contrastes da intimidade contemporânea. São Paulo: Cia. das Letras, 2004.

PUPPO, Eugênio. Ozualdo Ribeiro Candeias 80 anos. São Paulo: Heco Produções, 2002 .

RAMOS, Fernão; MIRANDA, Luiz Felipe (Orgs.). Enciclopédia do Cinema Brasileiro. São Paulo: Senac, 2000.

ROCHA, Glauber. Uma Estética da Fome. Revista Civilização Brasileira, n.3, Rio de Janeiro: Civilização Brasileira, p.165-170,1965. 
SCHVARZMAN, Sheila . Humberto Mauro e as imagens do Brasil. São Paulo: Editora Unesp, 2004.

SEVCENKO, Nicolau. Literatura como Missão: tensões sociais e criação cultural na

Primeira República. 3. ed., São Paulo: Brasiliense, 1989.

SOUZA, José Inácio de Melo. O Estado Contra os Meios de Comunicação (18891945). São Paulo: Annablume/Fapesp, 2003.

VERNET, Marc. Cinema e Narração. In: AUMONT, Jacques et al. A Estética do Filme. 2. ed. São Paulo: Papirus, 2002.

WISSENBACH, Maria Cristina Cortez. Da Escravidão à Liberdade: dimensões de uma privacidade possível. In: SEVCENKO, Nicolau (Org.). História da Vida Privada no Brasil v. 3: República: da Belle Époque à era do rádio. São Paulo: Cia. das Letras, 2004. XAVIER, Ismail. O Cinema Brasileiro Moderno. Rio de Janeiro: Paz e Terra, 2001. O Olhar e a Cena. São Paulo, Cosac \& Naïf, 2003.

TELES, Ângela Aparecida. An esthetics of precariousness: migration and intercultural exchanges in the cinema of Ozualdo Candeias (1967-92). História, São Paulo, v. 26, n. 2, p. 161-181, 2007.

Abstract: This article analyses the relation between cinema and history through the esthetics of the precariousness elaborated by a film director called Ozualdo Candeias. The mobility, the countryman orality as well as the precariousness esthetically worked out by mixing fiction and documentary, the disconstruction of classical cinema clichés are cultural trades between the urban world and the rural one raised by the industrialization and urbanization process intensified in the fifties of XXth century.

Keywords: cinema; esthetics of precariousness; Ozualdo Candeias.

Artigo recebido em 09/2007. Aprovado em 11/2007.

\section{NOTAS:}

\footnotetext{
${ }^{1}$ Este texto é parte da tese de minha autoria intitulada Cinema e Cidade: mobilidade, oralidade e precariedade no cinema de Ozualdo Candeias (1967-92), defendida em 2006, no Programa de PósGraduação em História da PUC-SP.

* Doutora em História Social pela PUC-SP; professora da FASP - Faculdades Associadas de São Paulo. E-mail: angteles@ig.com.br.

${ }^{2}$ Nestor Garcia Canclini entende por hibridação cultural "processos socioculturais nos quais estruturas ou práticas discretas que existiam de forma separada, se combinam para gerar novas estruturas, objetos e práticas". A fusão de "práticas discretas", que não são fontes puras, nos permite acompanhar os cruzamentos de fronteiras entre as práticas culturais congeladas historicamente sob o signo do popular, do erudito e do massivo. Também nos ajuda a pensar como as múltiplas temporalidades existentes sob essas classificações foram trabalhadas, ou seja, conceber a modernização latino-americana como tentativas de
} 
renovação com que diversos setores se encarregam da heterogeneidade multitemporal de cada nação (Canclini, 2003, p. XIX, 19).

3 Sobre a permanência da mobilidade como um traço constitutivo das populações pobres na contemporaneidade, ver Martins, in: Schwarcz, 2004, p. 659-726.

${ }^{4}$ Tomei essa imagem como referência a partir das reflexões de Ruy Gardnier, mas acredito que estética da precariedade é um conceito que melhor define os procedimentos inventivos de Candeias, em vez de "estética da brutalidade", cunhada por esse autor. Cf. Contracampo, 2004.

${ }^{5}$ Sheila Schvarzman historicizou a construção de Humberto Mauro como fundador do cinema brasileiro pelos cineastas do Cinema Novo. Suas imagens do Brasil foram alçadas por essa geração como matriz para uma cinematografia verdadeiramente nacional, sendo Glauber Rocha, Alex Vianny e Paulo Emílio Salles Gomes os mentores dessa operação. Já Candeias pensa que Humberto Mauro faz cinema essencialmente de matriz hollywoodiana. (Cf. SCHVARZMAN, 2005, principalmente Capítulo VI). Essa perspectiva de Candeias foi a mim explicitada em entrevista recente, set. 2004.

${ }^{6}$ Um exemplo da mobilidade como um imperativo na vida das populações do Brasil e a maneira como essas populações percebiam o tempo podem ser pensadas a partir de um relato colhido de um morador do Vale do Paraíba por Alceu Maynard: "afirmava ser voz corrente entre os moradores da região que 'quando uma pessoa se muda, na última viagem que faz com os terecos não deve olhar para trás, caso aconteça terá má sorte para o resto da vida” (Cf. Wissenbach, 2004, p. 69). 